\title{
Contribution of Alaskan glaciers to sea-level rise derived from satellite imagery
}

Berthier E. ${ }^{1,2}$, Schiefer E. ${ }^{3}$, Clarke G.K.C. ${ }^{4}$, Menounos B. ${ }^{5}$, Rémy F. ${ }^{1,2}$

${ }^{1}$ CNRS; LEGOS; 14 Av. Ed. Belin, F-31400 Toulouse, France

${ }^{2}$ Université de Toulouse; UPS (OMP-PCA); LEGOS; 14 Av. Ed. Belin, F-31400

Toulouse, France

${ }^{3}$ Department of Geography, Planning and Recreation; Northern Arizona University; Box 15016 Flagstaff, Arizona 86011-5016, USA

${ }^{4}$ Department of Earth and Ocean Sciences; University of British Columbia; 6339 Stores Road, Vancouver, BC, Canada V6T $1 Z 4$

${ }^{5}$ Geography Program and Natural Resources Environmental Studies Institute;

University of Northern British Columbia; Prince George, BC, Canada V2N 4Z9

\section{Full Reference:}

Berthier E., Schiefer E., Clarke G.K.C., Menounos B. \& Remy, F. Contribution of Alaskan glaciers to sea level rise derived from satellite imagery. Nature Geoscience, 3(2), 92-95, doi: 10.1038/ngeo737, 2010

The paper is also available at:

http://www.nature.com/ngeo/journal/v3/n2/full/ngeo737.html

Supplementary information is (freely) available at: http://etienne.berthier.free.fr/Berthier_et_al_NGeo_2010.htm 
Over the past 50 years, retreating glaciers and ice caps contributed $0.5 \mathrm{~mm}^{-1} \mathrm{r}^{-1}$ to sea-level rise ${ }^{1}$, and one third of this contribution is believed to come from ice masses bordering the Gulf of Alaska ${ }^{2,3}$. However, these estimates of ice loss in Alaska are based on measurements of a limited number of glaciers that are extrapolated to constrain ice wastage in the many thousands of others. Uncertainties in these estimates arise, for example, from the complex pattern of decadal elevation changes at the scale of individual glaciers and mountain ranges ${ }^{4-7}$. Here we combine a comprehensive glacier inventory with elevation changes derived from sequential digital elevation models. We find that between 1962 and 2006, Alaskan glaciers lost $41.9 \pm 8.6 \mathrm{~km}^{3} \mathrm{yr}^{-1}$ of water, and contributed $0.12 \pm 0.02 \mathrm{~mm} \mathrm{yr}^{-1}$ to sea-level rise, $34 \%$ less than estimated earlier ${ }^{2,3}$. Reasons for our lower values include the higher spatial resolution of our glacier inventory as well as the reduction of ice thinning underneath debris and at the glacier margins, which were not resolved in earlier work. We suggest that estimates of mass loss from glaciers and ice caps in other mountain regions could be subject to similar revisions.

The extent and high turnover rates of glaciers in Alaska and northwest Canada (Fig. 1), hereafter "Alaskan glaciers", make them a potentially important contributor to historical and future SLR. With the exception of a few tidewater glaciers, the majority have retreated since the late nineteenth century ${ }^{8}$. Previous efforts to estimate their mass loss since the 1950s have relied on extrapolating site-specific measurements to the entire region ${ }^{2,3,9}$. In their landmark study, Arendt et al. ${ }^{2}$, for example, used laser altimetry to measure elevation change on 67 glaciers covering $20 \%$ of the area of Alaskan glaciers.

We apply sequential DEM analysis ${ }^{10}$ to estimate the mass loss of Alaskan glaciers over the period 1962-2006. A digital glacier inventory, created by merging glacier outlines derived from US and Canadian maps (see Methods), indicates that the total icecovered area for the mid-to-late $20^{\text {th }}$ century is about $87,860 \mathrm{~km}^{2}$ (Table 1 ). This estimate is somewhat higher than the total area $\left(85,150 \mathrm{~km}^{2}\right)$ reported in Dyurgerov and Meier ${ }^{9}$ and in the gridded inventory of Cogley ${ }^{11}\left(80,430 \mathrm{~km}^{2}\right)$, but slightly lower than the $90,000 \mathrm{~km}^{2}$ value used by Arendt et $a l^{2}$. Our inventory, compiled from a variety of sources with different accuracies and different dates, better resolves small glaciers and emerging rock outcrops on large glaciers and icefields. For those few glaciers that advanced between the median date of the maps (1962) and of the satellite images (2006), the inventory was updated using 5-m (Spot5) and 15-m (ASTER) resolution satellite images.

We calculated ice elevation changes for nearly three quarters of the ice-covered areas in Alaska by subtracting an old DEM derived from map elevation contour lines from a recent DEM derived from Spot5 and ASTER images. To reduce systematic errors in our estimate of ice elevation changes, the two topographic datasets have each been adjusted to ICESat altimetric profiles (see Methods). Although random elevation errors are relatively high in the map ( $\pm 45 \mathrm{~m}$ in the accumulation area $\left.{ }^{2}\right)$ and in the satellite DEMs ( $\pm 15 \mathrm{~m}$ for ASTER ${ }^{12}, \pm 10 \mathrm{~m}$ for Spot $5^{13}$ ), they are reduced by averaging over vast regions (see Supplementary Notes). 


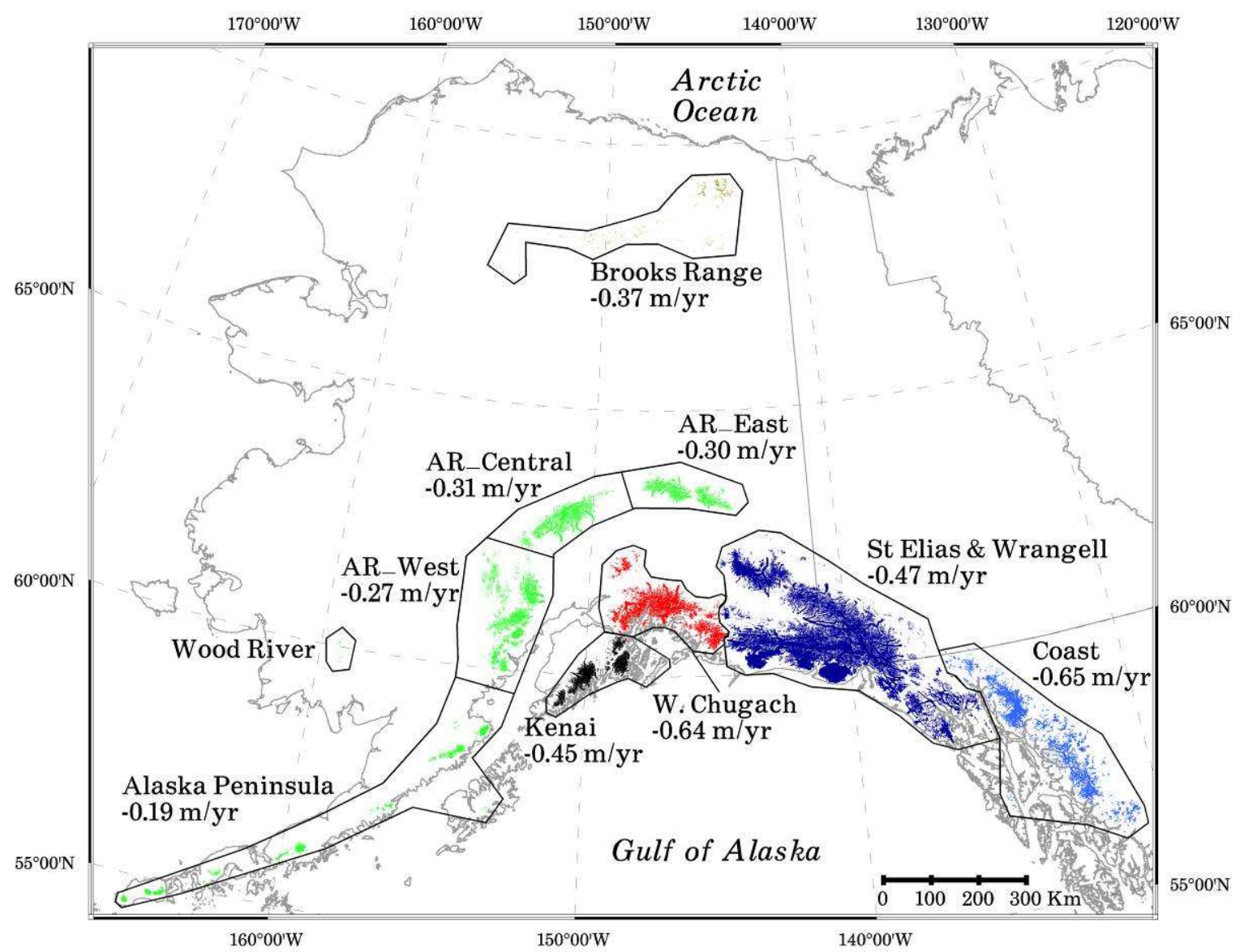

Figure 1: Regional area-average glacier mass balance in northwest North America between 1962 and 2006. The boundaries and names of the different glaciated regions follow those of Arendt $e t a{ }^{2}{ }^{2}$, except that the Wrangell Mountains have been included in the St Elias Mountains. AR stands for Alaska Range.

The complexity of glacier wastage during the period 1962-2006 is illustrated by ice loss in the Western Chugach Mountains (Fig. 2). Most glaciers thinned, especially for their low elevation tongues (Fig. 3). A few glaciers, such as tidewater Harvard Glacier thickened and advanced ${ }^{14}$. Columbia Glacier alone accounts for $42 \%$ of the ice loss in this mountain range. For this tidewater glacier, maximum thinning rates averaged $10 \mathrm{~m} \mathrm{yr}^{-1}$ during 1957-2007 but thinning accelerated after 1980, with the onset of rapid, frontal retreat ${ }^{15}$. Maps of ice elevation change for other Alaskan regions reveal the pattern of glacier changes over the past 50 years and their distribution with altitude (Supplementary Figs S1, S2). The heterogeneous ice elevation changes within each mountain range results from differences in glacier dynamics (many glaciers are surgetype, lake-terminating or tidewater) and in climate sensitivity (effect of debris cover, and distribution of ice with altitude $)^{4,5,14}$. The limited thinning or slight thickening at the highest elevations is consistent with the enhanced accumulation observed since 1950 in an ice core drilled at 5,340 m a.s.l. in the St. Elias Mountains ${ }^{16}$. 


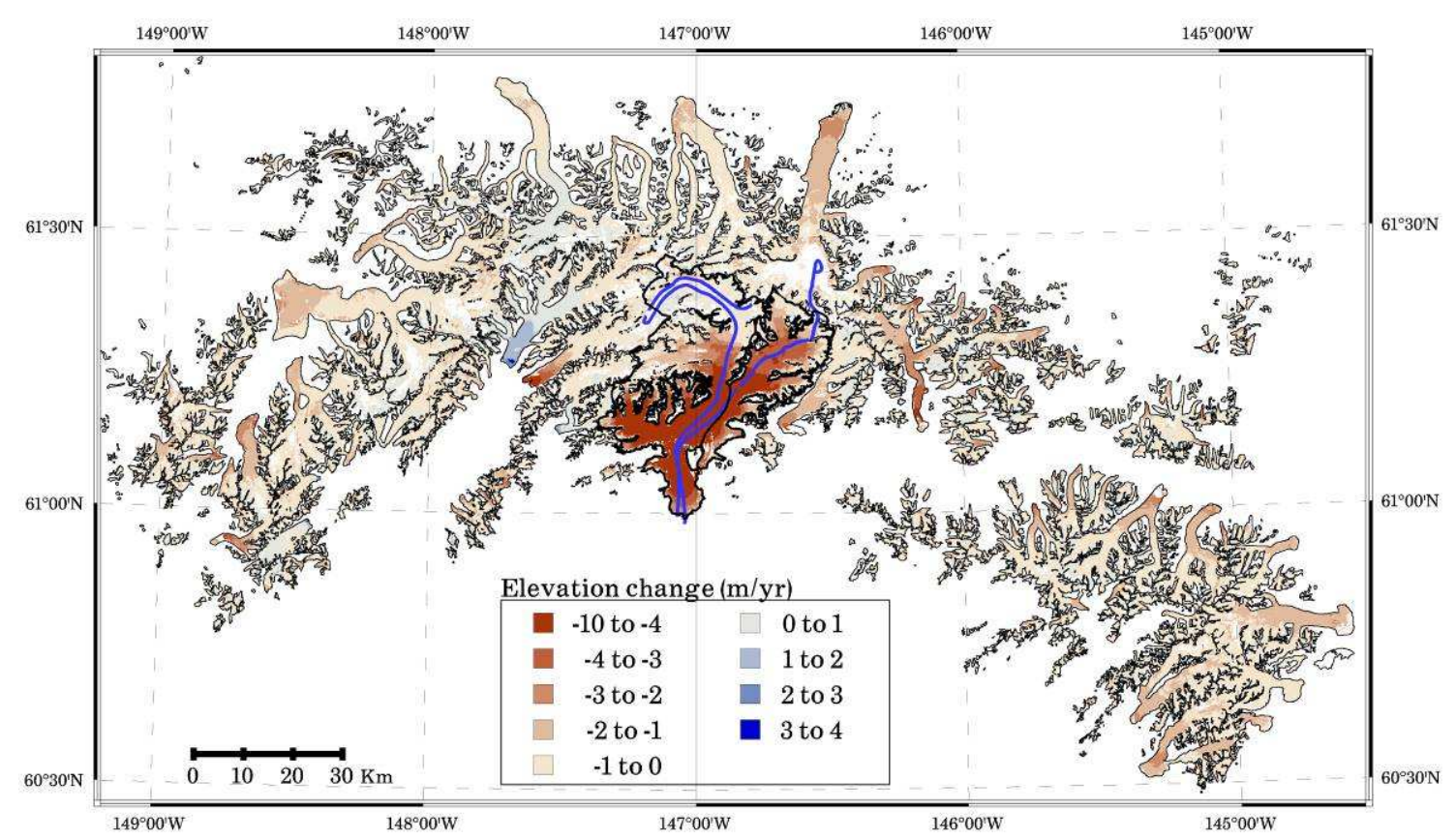

Figure 2: Map of surface elevation change in the Western Chugach Mountains between the 1950s and 2007. The thin black line corresponds to our new ice inventory. The thick black line is the outline of Columbia Glacier. The location of laser altimetry profiles used by Arendt $e t$ $a l^{2}$ to estimate the ice loss of Columbia Glacier are shown in blue. Regions where no reliable elevation changes could be measured are denoted in white.

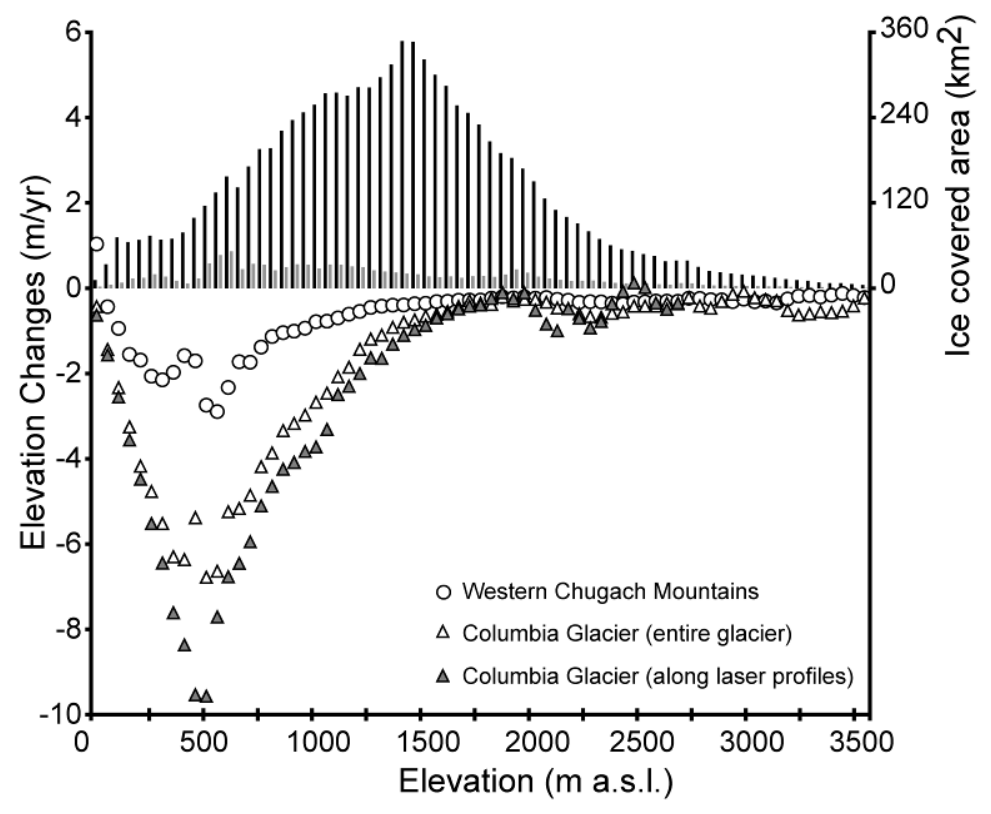

Figure 3: Hypsometry and rate of ice elevation change versus altitude in the Western Chugach Mountains. Upper panel, the hypsometry (distribution of ice-covered areas with altitude) is shown for the whole mountain range $\left(9,149 \mathrm{~km}^{2}\right)$ and Columbia Glacier $\left(1,066 \mathrm{~km}^{2}\right)$. Lower panel, 1957-2007 rate of ice elevation changes (averaged every 50-m elevation bins) extracted from the sequential DEM for the Western Chugach Mountains, the Columbia Glacier, and along the altimetric laser profiles (see Fig. 2) surveyed by Arendt et al. ${ }^{2}$

Our estimate of mass loss is supported by the lack of notable elevation bias in our datasets on ice free terrain (Supplementary Table S2) and the agreement between 
our geodetically-derived and field-based mass balances ${ }^{19}$ for Gulkana and Wolverine glaciers although the time intervals differ (Supplementary Table S3).

\begin{tabular}{|c|c|c|c|c|c|c|}
\hline Region & $\begin{array}{l}\text { Ice-covered } \\
\text { area }\left(\mathrm{km}^{2}\right)\end{array}$ & $\begin{array}{l}\text { Surveyed area } \\
(\%)^{*}\end{array}$ & Map date & Satellite date & $\begin{array}{l}\text { Ice loss } \\
\left(\mathrm{km}^{3} \mathrm{yr}^{-1} \text { w.e. }\right)\end{array}$ & $\begin{array}{l}\text { Area average } \\
\text { mass balance } \\
\left.\text { ( } \mathrm{m} \mathrm{yr}^{-1} \text { w.e. }\right)\end{array}$ \\
\hline Brooks Range & 598 & 1 & 1956 & 2002 & $0.18 \pm 0.05$ & $-0.37 \pm 0.06$ \\
\hline Alaska Range & 15,834 & 67 & 1953 & 2004 & $4.33 \pm 1.4$ & $-0.30 \pm 0.09$ \\
\hline Kenai Peninsula & 4,351 & 68 & 1950 & 2007 & $1.95 \pm 0.47$ & $-0.45 \pm 0.11$ \\
\hline Western Chugach Mountains & 9,149 & 82 & 1954 & 2006 & $5.81 \pm 0.66$ & $-0.64 \pm 0.07$ \\
\hline St Elias and Wrangell Mountains & 45,905 & 75 & 1968 & 2006 & $21.66 \pm 4.4$ & $-0.47 \pm 0.09$ \\
\hline Coast Mountains & 12,026 & 72 & 1966 & 2007 & $7.88 \pm 1.6$ & $-0.65 \pm 0.14$ \\
\hline Alaskan Glaciers & 87,862 & 73 & 1962 & 2006 & $41.9 \pm 8.6$ & $-0.48 \pm 0.10$ \\
\hline
\end{tabular}

To compare our results to Arendt $e t$ al. $^{2}$, we time-weighted their ice loss for 1962-1995 and 1995-2006 by assuming that the loss for 2001-2006 equals that measured for 1995-2001 and constructed a single estimate for 1962-2006. The extension for 2001-2006 is consistent with field-based annual mass balance measurements ${ }^{19}$ and with a recent analysis based on GRACE gravity fields ${ }^{20}$. Our estimate is $34 \%$ smaller than the $62.7 \pm 19.9 \mathrm{~km}^{3} \mathrm{yr}^{-1}$ w.e. ice loss $\left(0.17 \pm 0.05 \mathrm{~mm} \mathrm{yr}^{-1} \mathrm{SLR}\right)$ based on airborne laser altimetry ${ }^{2}$. Uncertainties are large in both our estimate and the one of Arendt et al. ${ }^{2}$ and arise mainly from the uncertainties of the old contour maps (Supplementary Table S1). Because the same maps were used, however, this source of error is shared by both estimates and thus, we constructed an error estimate that applies only to differences in ice loss (Supplementary Notes). Our revised value is $20.8 \pm 4.8 \mathrm{~km}^{3} \mathrm{yr}^{-1}$ w.e. lower than the laser altimetry ice loss.

Regional extrapolation to unsurveyed ice masses is a potentially important source of uncertainty ${ }^{14}$. Unmeasured glaciers covered $80 \%$ in the laser altimetry study ${ }^{2}$ but only $27 \%$ in our sequential DEM analysis. Three other factors, taken together, could explain why Arendt et $a .^{2}$ overestimated the ice loss:

(i) Their glacier inventory had a lower resolution and overestimated the Alaskan ice-covered area by $2 \%$.

(ii) No correction was made for the insulating effect of debris cover. Thinning rates on debris-covered glaciers differ considerably from rates measured for non-debris covered ice when influenced by similar climate ${ }^{10}$. Our maps of ice elevation changes show that debris-covered glaciers experienced lower thinning rates. At low elevation, on Bering Glacier, for example, we observe a twofold reduction of thinning rates under debris compared to debris-free ice. If elevation changes on debris-free ice were assumed to be representative of the whole Bering Glacier, the total ice loss for this glacier would be overestimated by $13 \%$. Many Alaskan glaciers are partly debris-covered and the mass lost from these glaciers will be lower than for non debris-covered ice. This effect is implicitly included in our sequential DEM analysis.

(iii) For individual glaciers, Arendt et al. $^{2}$ measured elevation changes along two or three profiles, generally following a central flowline, and from this information the 
glacier-wide changes were estimated. Though seemingly innocent, this method can lead to a systematic overestimation of ice loss. The amount of downwasting cannot exceed the ice thickness so thinning at the glacier margins is typically lower that that observed along its central flowline ${ }^{21}$. In contrast, sequential DEMs provide a nearly complete coverage of ice elevation changes and allows us to assess the magnitude of errors associated with this flowline sampling bias. For Columbia Glacier, one of the largest contributor to SLR among Alaskan glaciers, thinning is overestimated along laser altimetry profiles below $1500 \mathrm{~m}$ a.s.l. and the glacier-wide estimate of ice loss is inflated by $27 \%$ (Fig. 3 and Supplementary Fig. S3). Similar comparisons were made for other large glaciers in the Arendt et al. ${ }^{2}$ dataset and, in total, we found that altimetrysimulated ice loss exceeds actual ice loss by $22 \%$ (Supplementary Table S4). The magnitude and sign of the bias in the ice loss due to central flowline sampling varies among the glaciers and depends on how reliably the profiles captured the across-flow variations in elevation change. We find no simple relation in our data that could be used to improve calculations of ice loss based on laser profiling.

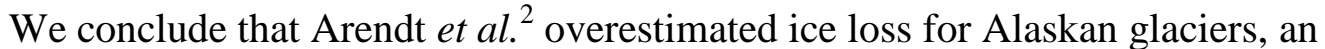
opposite conclusion to that of Larsen $e t a .^{4}$ who also used sequential DEM analysis to find that Arendt et $a ._{.}{ }^{2}$ underestimated the ice loss by more than a factor of two for a $14,500 \mathrm{~km}^{2}$ ice-covered area in the Coast and southern St. Elias mountains. In fact, our results are compatible with Larsen et al. ${ }^{4}$ because in this area, our ice loss (12.5 \pm 2.0 $\mathrm{km}^{3} \mathrm{yr}^{-1}$ w.e. $)$ is close to the Larsen et al. ${ }^{4}$ value $\left(15 \pm 4.0 \mathrm{~km}^{3} \mathrm{yr}^{-1}\right.$ w.e. $)$ and, therefore, remains higher than the ice loss previously reported by Arendt et al. ${ }^{2}$.

Repeat airborne laser profiling is an efficient means to detect changes in the rate of ice loss along the centreline for a given glacier $^{22}$, but new approaches are required to scale these measurements up to an entire glacier and glaciated region. Where such data exist, we advocate the use of sequential DEMs to obtain a comprehensive view of GIC contributions to SLR for other regions that contain sizeable fractions of global ice cover. Such regionally-integrated measurements could be compared to results obtained through grid-based mass balance modelling ${ }^{23}$ to resolve the relative role played by surface mass balance and tidewater dynamics in the regional ice wastage, and thus better constrain the future GIC contribution to $\operatorname{SLR}^{17,24}$. This is crucial given that SLR is one of the major socio-economic hazards associated with global warming ${ }^{25}$.

\section{METHODS}

Glacier inventory. In Alaska (AK), our glacier inventory is based on the Digital Line Graph (DLG) files that contain all water features digitized from the United State Geolocical Survey (USGS) 1:63,360-scale, 15 minute topographic maps. In southeast Alaska, most DLG files were missing. Instead, we used the inventory compiled by Beedle ${ }^{26}$ for the largest icefields complemented with smaller ice masses extracted from the USGS National Hydrographic Database. For the Yukon Territory (YT), glacier extents were extracted from the 1:50,000-scale Canadian National Topographic Database and in British Columbia (BC) the 1:20,000-scale Terrain Resource Information Management database ${ }^{6}$. Minimal manual editing was performed to correct some obvious errors, otherwise we rely on the capacity of the original cartographers to identify and outline each ice mass.

Map DEMs. DEMs derived from the original map contour lines have been obtained from the USGS for AK, Geomatics Yukon for YT and GeoBC for BC. In AK and YT, the vertical reference for altitude is the National Geodetic Vertical Datum 1929 which differ from the Earth Geopotential Model 1996 vertical reference used for recent satellite DEMs ${ }^{4}$. To account for this difference, we systematically compared AK 
and YT DEMs with ICESat data ${ }^{27}$ on the ice free terrain. On average, we found AK and YT map elevations to be $2.5 \mathrm{~m}$ higher than ICESat data (standard deviation of 20-25 m), in good agreement with the $2.3 \mathrm{~m}$ offset calculated by Larsen et al. ${ }^{4}$. Thus, $2.5 \mathrm{~m}$ has been subtracted from AK and YT DEMs before comparison with recent satellite data.

Satellite DEMs. Where available, we used a 40-m DEM derived from Spot5-HRS images acquired during the SPIRIT project ${ }^{13}$. Accuracy in glaciated areas is better than $\pm 10 \mathrm{~m}$ (refs 7,13). Unreliable elevations have been masked using the score channel. No Spot5-HRS DEM is available in the Alaska Range, Alaska Peninsula, and in part of the St Elias and Coast mountains. Some of these gaps were filled with ASTER 30-m DEMs calculated using the SILCAST software with an accuracy of $\pm 15 \mathrm{~m}$ (ref. 12). Images as close as possible to the end of the ablation period (mid-September in Alaska) were selected to minimize errors due to seasonal elevation changes. The acquisition dates of all images are listed in Supplementary Table S5. Both ASTER and Spot5-HRS DEMs are automatically derived from stereoimagery without ground control points and, thus, may contain some planimetric and altimetric biases ${ }^{8,16}$. These biases have been estimated and corrected using ICESat data acquired closest in time to the acquisition date of the satellite-derived DEM. For each ICESat footprint, the corresponding DEM elevation was extracted by bilinear interpolation. All data points for which the absolute elevation differences were greater than $70 \mathrm{~m}$ were considered as outliers. The planimetric shift was corrected by minimizing the standard deviation of these elevation difference ${ }^{8}$. Elevation differences were then plotted as a function of altitude and a least squares adjustment was used to model the elevation bias ${ }^{28}$. The parameters of this adjustment ( $\alpha$, the slope and $\beta$, the vertical offset at sea level) are provided for each satellite DEM in Supplementary Table S5. When the same glaciated area was covered by different DEMs, we chose the one that had the lowest standard deviation of the elevation differences when compared to ICESat data.

Volumes changes in unsurveyed areas. Glacier volume change for the $27 \%$ of unmeasured glaciated areas was estimated by integrating the measured elevation changes over the altitude distribution of unmeasured areas in each mountain range. This value was added to the measured changes to obtain a total volume change in each region. For the Brooks Range and most of the Aleutian Islands and Alaska Peninsula (Fig. 1), the USGS maps have a poor geodetic control ${ }^{29}$ and the coverage using satellite data is limited, so that it was not possible to reliably measure elevation changes. In the Brooks Range, we use the specific mass balance of McCall Glacier ${ }^{30}$ and following Rabus and Echelmeyer ${ }^{29}$, assumed that this glacier was representative for the whole mountain range. In the Aleutian Islands and Alaska Peninsula, we applied the specific mass balance measured from sequential DEMs on two icefields around Mt Katmai (covering $580 \mathrm{~km}^{2}$ ) to other ice-covered areas (totalizing $2630 \mathrm{~km}^{2}$ ). The volume changes for these regions are more uncertain but they have small ice-covered areas and contribute less than $2 \%$ to the overall ice loss.

Conversion to regional mass balance and SLR. Total ice volume change in each region is converted to mass change assuming a constant density of $900 \mathrm{~kg} \mathrm{~m}^{-3}$. After dividing the mass loss by the maximum ice extent, we obtain an area-weighted mass balance for each mountain range. The total mass loss from Alaskan glaciers is converted to changes in sea level after dividing by the area $\left(362 \times 10^{6} \mathrm{~km}^{2}\right)$ of the global ocean ${ }^{23}$.

Supplementary Information is linked to the online version of the paper at www.nature.com/nature

Acknowledgments We thank C. Larsen, R. Muskett, A. Arendt, S. Zirnheld and M. Wilkie for information concerning the USGS and Yukon maps. We also thank A. Cazenave for comments on an earlier version of this manuscript. Spot5 DEMs are courtesy of the SPIRIT project, ASTER DEMs of the GLIMS project. Laser altimetry profiles were provided by the University of Alaska Fairbanks through the National Snow and Ice Data Center. EB acknowledges support from the CNES (TOSCA, ISIS); GC and BM support from the Polar Climate Stability Network and the Western Canadian Cryospheric Network, both funded by the Canadian Foundation for Climate and Atmospheric Sciences, and from the Natural Sciences and Engineering Research Council of Canada.

Author Contributions EB led the development of this study. All authors discussed the results and commented on the manuscript at all stages.

Author Information Correspondence should be addressed to: etienne.berthier@legos.obs-mip.fr 
References

1. Kaser, G., Cogley, J.G., Dyurgerov, M.B., Meier, M.F. \& Ohmura, A. Mass balance of glaciers and ice caps: Consensus estimates for 1961-2004. Geophys Res Lett 33, L19501 (2006).

2. Arendt, A.A., Echelmeyer, K.A., Harrison, W.D., Lingle, C.S. \& Valentine, V.B. Rapid wastage of Alaska glaciers and their contribution to rising sea level. Science 297, 382386 (2002).

3. Meier, M.F. \& Dyurgerov, M.B. Sea level changes: How Alaska affects the world. Science 297, 350-351 (2002).

4. Larsen, C.F., Motyka, R.J., Arendt, A.A., Echelmeyer, K.A. \& Geissler, P.E. Glacier changes in southeast Alaska and northwest British Columbia and contribution to sea level rise. J Geophys Res-Earth 112, F01007 (2007).

5. $\quad$ Muskett, R.R., Lingle, C.S., Tangborn, W.V. \& Rabus, B.T. Multi-decadal elevation changes on Bagley Ice Valley and Malaspina Glacier, Alaska. Geophys Res Lett 30(2003).

6. Schiefer, E., Menounos, B. \& Wheate, R. Recent volume loss of British Columbian glaciers, Canada. Geophys Res Lett 34, 1-6 (2007).

7. Berthier, E. \& Toutin, T. SPOT5-HRS digital elevation models and the monitoring of glacier elevation changes in North-West Canada and South-East Alaska. Remote Sens Environ 112, 2443-2454 (2008).

8. Molnia, B.F. Late nineteenth to early twenty-first century behavior of Alaskan glaciers as indicators of changing regional climate. Global Planet Change 56, 23-56 (2007).

9. Dyurgerov, M.B. \& Meier, M.F., Glaciers and the Changing Earth System: a 2004 Snapshot. (INSTAAR, Boulder, 2005).

10. Berthier, E., Arnaud, Y., Baratoux, D., Vincent, C. \& Remy, F. Recent rapid thinning of the "Mer de Glace" glacier derived from satellite optical images. Geophys Res Lett 31, L17401 (2004).

11. Cogley, J.G., in Encyclopedia of Hydrological Sciences, edited by M.G. Anderson (John Wiley, Malden, Mass., 2005), Vol. 4, pp. 2555- 2573.

12. Fujisada, H., Bailey, G.B., Kelly, G.G., Hara, S. \& Abrams, M.J. ASTER DEM performance. IEEE T Geosci Remote 43, 2707-2714 (2005).

13. Korona, J., Berthier, E., Bernard, M., Remy, F. \& Thouvenot, E. SPIRIT. SPOT 5 stereoscopic survey of Polar Ice: Reference Images and Topographies during the fourth International Polar Year (2007-2009). ISPRS J Photogramm 64, 204-212 (2009).

14. Arendt, A. et al. Updated estimates of glacier volume changes in the western Chugach Mountains, Alaska, and a comparison of regional extrapolation methods. J Geophys Res-Earth 111(2006).

15. O'Neel, S., Pfeffer, W.T., Krimmel, R. \& Meier, M.F. Evolving force balance at Columbia Glacier, Alaska, during its rapid retreat. J Geophys Res-Earth 110(2005).

16. Moore, G.W.K., Holdsworth, G. \& Alverson, K. Climate change in the North Pacific region over the past three centuries. Nature 420, 401-403 (2002).

17. Gregory, J.M. \& Oerlemans, J. Simulated future sea-level rise due to glacier melt based on regionally and seasonally resolved temperature changes. Nature 391, 474-476 (1998).

18. Domingues, C.M. et al. Improved estimates of upper-ocean warming and multi-decadal sea-level rise. Nature 453, 1090-1093 (2008).

19. Josberger, E.G., Bidlake, W.R., March, R.S. \& Kennedy, B.W. Glacier mass-balance fluctuations in the Pacific Northwest and Alaska, USA. Ann Glaciol 46, 291-296 (2007). 
20. Luthcke, S.B., Arendt, A.A., Rowlands, D.D., McCarthy, J.J. \& Larsen, C.F. Recent glacier mass changes in the Gulf of Alaska region from GRACE mascon solutions. $J$ Glaciol 54, 767-777 (2008).

21. Koch, J., Menounos, B. \& Clague, J.J. Glacier change in Garibaldi Provincial Park, southern Coast Mountains, British Columbia, since the Little Ice Age. Global Planet Change 66, 161-178 (2009).

22. Arendt, A.A., Walsh, J. \& Harrison, W. Changes of Glaciers and Climate in Northwestern North America during the Late 20th Century. J Climate 22, 4117-4134 (2009).

23. Hock, R., de Woul, M., Radic, V. \& Dyurgerov, M. Mountain glaciers and ice caps around Antarctica make a large sea-level rise contribution. Geophys Res Lett 36(2009).

24. Raper, S.C.B. \& Braithwaite, R.J. Low sea level rise projections from mountain glaciers and icecaps under global warming. Nature 439, 311-313 (2006).

25. Milne, G.A., Gehrels, W.R., Hughes, C.W. \& Tamisiea, M.E. Identifying the causes of sea-level change. Nat Geosci 2, 471 - 478 (2009).

26. Beedle, M., in GLIMS Glacier Database (National Snow and Ice Data Center/World Data Center for Glaciology. Digital Media, Boulder, CO, 2006).

27. Zwally, H.J. et al. ICESat's laser measurements of polar ice, atmosphere, ocean, and land. J Geodyn 34, 405-445 (2002).

28. Kääb, A. Glacier Volume Changes Using ASTER Satellite Stereo and ICESat GLAS Laser Altimetry. A Test Study on Edgeoya, Eastern Svalbard. IEEE T Geosci Remote 46, 2823-2830 (2008).

29. Rabus, B.T. \& Echelmeyer, K.A. The Mass Balance of McCall Glacier, Brooks Range, Alaska, U.S.A.; its Regional relevance and Implications for Climate Change in the Arctic. J Glaciol 44, 333-351 (1998).

30. Nolan, M., Arendt, A., Rabus, B. \& Hinzman, L. Volume change of McCall Glacier, Arctic Alaska, USA, 1956-2003. Ann Glaciol 42, 409-416 (2005). 